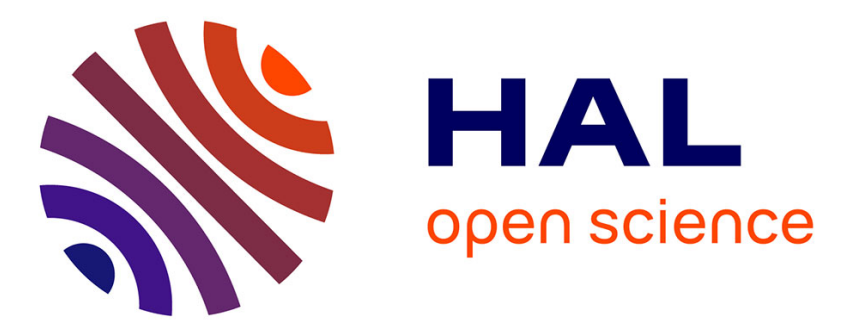

\title{
Using a fire propagation model to assess the efficiency of prescribed burning in reducing the fire hazard
}

Nathalie Cassagne, François Pimont, J.-L. Dupuy, R.R. Linn, Anders Mårell, Chloe Oliveri, Eric Rigolot

\section{- To cite this version:}

Nathalie Cassagne, François Pimont, J.-L. Dupuy, R.R. Linn, Anders Mårell, et al.. Using a fire propagation model to assess the efficiency of prescribed burning in reducing the fire hazard. Ecological Modelling, 2011, 222 (8), pp.1502-1514. 10.1016/j.ecolmodel.2011.02.004 . hal-02594956

\section{HAL Id: hal-02594956 \\ https: / hal.inrae.fr/hal-02594956}

Submitted on 29 May 2020

HAL is a multi-disciplinary open access archive for the deposit and dissemination of scientific research documents, whether they are published or not. The documents may come from teaching and research institutions in France or abroad, or from public or private research centers.
L'archive ouverte pluridisciplinaire HAL, est destinée au dépôt et à la diffusion de documents scientifiques de niveau recherche, publiés ou non, émanant des établissements d'enseignement et de recherche français ou étrangers, des laboratoires publics ou privés.

\section{(ㅇ)(1) $\$$}

Distributed under a Creative Commons Attribution - NonCommercial - NoDerivatives| 4.0 
Using a fire propagation model to assess the efficiency of prescribed burning in reducing the fire hazard

7 Nathalie Cassagne ${ }^{\mathrm{a},{ }^{*}}$, François Pimont ${ }^{\mathrm{a}}$, Jean-Luc Dupuy ${ }^{\mathrm{a}}$, Rodman R. Linn ${ }^{\mathrm{b}}$, Anders Mårell $^{\mathrm{ac}}$, 8 Chloé Oliveri $^{\mathrm{a}}$, Eric Rigolot ${ }^{\mathrm{a}}$

${ }^{a}$ INRA-UR629, Ecologie des Forêts Méditerranéennes (URFM), Site Agroparc, Domaine 12 Saint Paul, F-84914, Avignon, France.

13 b Los Alamos National Laboratory MS: D401, Los Alamos, New Mexico, 87544, USA.

${ }^{\mathrm{c}}$ CEMAGREF, UR EFNO, F-45290 Nogent-sur-Vernisson, France.

* Corresponding author. Telephone: +33 4 32722921; fax: +33 4 32722902; email: nathalie.cassagne@avignon.inra.fr 


\section{Abstract}

2

3 We examined how fire hazard was affected by prescribed burning and fuel recovery over the

4 first six years following treatment. Eight common Mediterranean fuel complexes managed by 5 means of prescribed burning in limestone Provence (South-Eastern France) were studied, 6 illustrating forest and woodland, garrigue and grassland situations. The coupled atmosphere7 wildfire behaviour model FIRETEC was used to simulate fire behaviour (ROS, intensity) in 8 these complex vegetations. The temporal threshold related to the effectiveness of prescribed 9 burning in reducing the fire hazard was assessed from derivated fuel dynamics after treatment. 10 The study showed that prescribed burning treatment was effective for the first two years in most of the Mediterranean plant communities analysed. Thereafter, all forests and shrublands were highly combustible with a fire line intensity of more than $5000 \mathrm{~kW} / \mathrm{m}$ except for pine stands with or without oak (medium intensity of $2000 \mathrm{~kW} . \mathrm{m}^{-1} 3$ years after treatment). Low

14 fire line intensity $\left(900 \mathrm{~kW} . \mathrm{m}^{-1}\right)$ was obtained for grassland which was entirely treatment15 independent since the resprouter hemicryptophyte, Brachypodium retusum, is highly resilient 16 to fire. Fire behaviour was greatly affected by fuel load accumulation of Quercus ilex in woodland, and by standing necromass of Rosmarinus officinalis in treated garrigue. Pure pine stands with shrub strata similar to garrigue showed a lower fire intensity due to wind speed decrease at ground level under tree canopy, underlining the advantage of maintaining a proportion of canopy cover in strategic fuel-break zones.

\section{Keywords}

Mediterranean fuel complexes; prescribed burning; fuel dynamics; FIRETEC; fire behaviour. 


\section{Introduction}

Prescribed burning corresponds to the controlled application of fire to vegetation in either its natural or a modified state, under specified environmental conditions that allow the fire to be confined to a predetermined area while at the same time limiting fire intensity and rate of spread to the requirements of planned resource management objectives (FAO and GFMC, 2003). Prescribed burning is used in most parts of the world, but for different purposes such as for regenerating forests, clearing virgin land for cultivation, managing pasture-land and preserving fire-dependent plants and animals (Wade and Lunsford, 1989). In some countries of the Mediterranean (France, Spain, Portugal, ...), and in North America and Australia, prescribed burning is an integral part of fire prevention as it is primarily used to control fuel build-up at strategic places in wildland areas and thereby reduce the wildland fire hazard (Wright and Bailey, 1982; Sneeuwjagt, 1994; NIFC, 2001; Lazaro, 2008).

Fuel modification is the main option used to reduce the fire risk. Fuel treatments can be applied extensively onto the landscape to modify fire behaviour by fuel reduction (Finney, 2001; Pyne and Laven, 1996) or locally onto fuel breaks to contain a fire. Green (1977) defines a fuel-break as "a strategically located wide block, or strip, on which a cover of dense, heavy, or flammable vegetation has been permanently changed to one of lower volume or reduced flammability". Wildfire containment by fuel isolation in a network of fuel breaks is the main option adopted in South Eastern France (Rigolot and Alexandrian, 2006; Xanthopoulos et al., 2006), though such infrastructure may also be assigned to decreasing fire ignition events or decreasing the effects of fire on people and property (Rigolot, 2002). The effectiveness of fuel breaks has been discussed by several authors (Agee et al., 2000; Rigolot, 2002; Rigolot et al., 2004) and results have shown that isolation by fuel breaks can be efficiently improved by combining with area-wide fuel modification (Agee et al., 2000). European forest managers use a variety of fuel modification techniques including mechanical treatment, controlled grazing, herbicides and prescribed burning (Rigolot et al., 2009), either separately or in combination. Although mechanical treatment is the most common fuel reduction technique in South European countries, prescribed burning is increasingly being considered in Southern Europe, with contrasted levels of adoption between countries (Lazaro, 2008). Prescribed burning as a fuel reduction technique is more likely to be used extensively on the landscape (Fernandes and Botelho, 2003), but can also be employed to maintain fuel breaks (Xanthopoulos et al., 2006). 
1 Active prescribed burning plans for purposes of fuel reduction need to be assessed and

2 monitored to optimize the fire return interval and the spatial pattern of fire application.

3 Fernandes and Botelho (2003) analysed three approaches to assessing the effectiveness of

4 burning in reducing the fire hazard: computer simulation of fire propagation models, an

5 analysis of case studies, and changes in fire regimes.

Fire propagation models can be used to predict the effect of fuel reduction on a potential fire hazard. Three main types of models have been developed to assess fire behaviour. Empirical, quasi-physical and physically-based (Sullivan 2009 a and b). Empirical models are based on correlation between experimental fire spread rate and weather, fuel and terrain characteristics (see for example McArthur 1966) and their calibration required a significant number of experimental fires within a given fuel type. Using this type of models is not really appropriate to investigate fuel reduction effects in multiple fuel types, unless if a large data set of experimental fire is available, which is scarcely the case. Quasi-physical models are based on a simple analysis of fire physics to assess basic relationships, using parameters. These parameters are derived from laboratory experiments. The most famous model in this category is BEHAVE fire behaviour prediction and fuel modelling system (Burgan and Rothermel, 1984). Since it takes into account direct fuel characteristics, such as fuel load, moisture content and fuel particle thickness, it can provide a prediction of fire spread rate and intensity, within any given fuel type when main fuel characteristics are known. For this reason, this model has been widely used for this purpose (Loureiro et al., 2002; Stephens, 1998; Stephens and Moghaddas, 2005; van Wagtendonk, 1996; Finney et al., 2007). However, a very significant limitation of quasi-physical models is the fact that they do not explicitly take into account the 3D structure of the fuel. For example, BEHAVE averages in a unique layer all the fuel available and only consider fuel below approximately $6 \mathrm{~m}$. Fuel structure after treatment is very heterogeneous with clumps of fuel with very different properties: unburnt old fuel, burnt dead fuel, young resprouters have very different load and moisture. Averaging these clumps of fuel without taking into account distances between them is probably a very coarse assumption. More recently, physically-based fire models that explicitly take the spatial structure of the fuel has been developed (Linn 1997; Morvan \& Dupuy 2001; Mell et al. 2007). These computational fluid dynamic models (cfd) have demonstrated their ability to take fuel structure into account when assessing the impact of fuel treatment on fire propagation (Dupuy and Morvan, 2005; Linn et al., 2005b; Parsons, 2007; Pimont et al., 
1 turbulent regime, with short periods of gusts due to Kelvin-Helmholtz instabilities (Finnigan, 2 2000). The more complex the fuel structure, the more complex this behaviour with a 3 multitude of small scale heterogeneities resulting from prescribed burning. Physical models can be very valuable in this context because they are able to take account of the small-scale heterogeneities that are solved on their mesh. The FIRETEC modelling system is a threedimensional, two-phase transport model that solves the conservation equations of mass, momentum, energy and chemical species (Linn, 1997; Linn and Cunningham, 2005; Pimont et al., 2009). FIRETEC includes representations of vegetation used for the simulation of turbulent flows and fire propagation $(\sim \mathrm{m})$ within and above heterogeneous vegetation canopies. Simulations can be run on a two-metre scale near the ground. Fuel structure can be taken into account explicitly at this scale, and its impact on fire behaviour investigated (Linn et al., 2005a; Pimont et al., 2010). FIRETEC can be used to assess two major components of wildland fire risk by calculating fire rate of spread, and fire line intensity and duration. Fire rate of spread (ROS) quantifies the propagation danger part of a fire. Fire line intensity and duration express the effects of a fire on the ecosystem, i.e. ecosystem vulnerability. FIRETEC can be used to compute variables characterizing wildland fire behaviour including fire rate of spread, fire line intensity and fire line duration (residence time). Fire rate of spread and intensity are used to assess fire hazard, fire line intensity and duration influence the effects of fire on the ecosystem and are important to assess ecosystem vulnerability. Fire hazard combines with ecosystem vulnerability to constitute the wildland fire risk (Marzano et al., 2006).

A prescribed burning programme has been ongoing in the Petit Luberon State forest (SouthEastern France) since 1992. After an eight-year long initial trial and adjustment period, the programme has been fully operational since 2000, although the annual area burnt has been kept relatively low (20-30 ha) due to the short supply of trained personnel, and administrative and climatic constraints. Managers of the Luberon State forest promote prescribed burning combined with controlled grazing because these techniques are more cost effective and more efficient in reducing fine and dead fuel material than the mechanical clearing used in the past. In the present study, the FIRETEC fire propagation model was used to assess fire behaviour in structurally different successional stages of some common Mediterranean ecosystems in the Luberon State forest following prescribed burning treatments. The specific aims of this study were (i) to determine the reduction in fire hazard induced by prescribed burning, and (ii) 
1 whether the use of prescribed burning for reducing fire hazard is more appropriate in certain

2 fuel complexes than in others (in terms of efficiency of the intensity reduction), and thereby 3 contribute new knowledge to help improve prescribed burning practices.

\section{Material and methods}

\subsection{Study area}

The Luberon forest area $\left(43^{\circ} 48^{\prime} 00^{\prime}\right.$ 'N, $5^{\circ} 20^{\prime} 00^{\prime}$ 'E) corresponds to a limestone formation emerging between the Durance River and the Calavon plains in South-Eastern France near Avignon. We focused for this work on the State forest (3,312 ha) of the Petit Luberon forest area (14,000 ha), which included two (Trou-du-Rat and Mayorques) of the five fuel breaks in this area located in the western part of the Luberon forest area (21,365 ha) (Fig. 1). The fuel breaks date back to the last major wildfires in 1989 and 1991 that led to the conception of a fire prevention management plan for the Petit Luberon forest area based on a network of 5 strategic fuel breaks. The fuel breaks are managed by the State Forest Service which uses a combination of clearing treatments, grazing and prescribed burning to reduce the build up of fuel loads. The landscape consists of a rough topography of great heritage value between 110 $\mathrm{m}$ and $720 \mathrm{~m}$ a.s.1. The climate is typically Mediterranean with hot dry summers, a mean annual temperature of $13.6^{\circ} \mathrm{C}$ and mean annual precipitation of $677.5 \mathrm{~mm}$.

[Fig. 1]

\subsection{Vegetation types}

The dominant vegetation in the State forest area consists of Holm oak (Quercus ilex) coppice forests accounting for $44.7 \%$ and pure or mixed (with Holm oak) Aleppo pine (Pinus halepensis) forests accounting for $15.3 \%$ (ONF, 2008). Shrublands are also widespread over a total area of 923 ha (28\%) consisting mainly of xerophilous garrigue made up of Kermes oak (Quercus coccifera) with aromatic plants. The last dominant vegetation type is grassland covering $7 \%$ of the surface area (Fig. 1). The remaining $5 \%$ consists of pine and cedar plantations, and deciduous tree stands that we did not take into account in this work.

34 Yearly monitoring of shrub stratum phytovolume has been used by forest managers as a fuel 
1 encroachment indicator to assess the forest fire risk (Etienne and Rigolot, 2001). The method 2 consist in visualy estimating the heights and the cover fractions of the 3 main shrub species 3 for each mapping unit. When total shrub cover is higher than the sum of three specific covers, 4 it is also taken into account with the list of the most represented complementary species. Fuel 5 reduction treatments are scheduled when the phytovolume exceeds the threshold value of $62500 \mathrm{~m}^{3} \cdot \mathrm{ha}^{-1}$ (Etienne et al. 1991; Beylier et al., 2006). We used the phytovolume field survey 7 carried out by the State Forest Service from 2003 to 2006 to select and describe the most 8 common plant communities in the two fuel breaks (Trou-du-Rat and Mayorques) to be used 9 for fire simulations. Phytovolume data can provide a precise classification of vegetation types and establish composition in terms of the main species represented. Eight plant communities were selected on the basis of this database and their current distribution in the two fuel break areas was checked. Fuel complexes at the control stage were also characterized by field descriptions in the State forest where the vegetation is not treated. For each plant community, the cover fraction and the height of the dominant shrub species were determined on an area of about $1000 \mathrm{~m}^{2}$ as well as tree characteristics (cover, height, dbh) when the strata was present. These observations were used to build the virtual fuel complexes used in the simulations and presented in Table 1.

[Table 1]

\subsection{Fuel build-up dynamics after prescribed burning}

23 Prescribed burning consists of low intensity fires that generally do not impact on trees but reduces fine fuels in lower strata. We therefore considered vegetation dynamics only for the shrub and herbaceous layers in the various post-treatment stages. Moreover, forest managers of the Luberon State forest take into account the fire risk but also the conservation of the natural biodiversity. In that way, prescribed burning teams didn't burn all the area treated but maintained patches of unburnt vegetation that created a vegetation mosaic favourable to wildlife (Pons et al., 2003). We took into account this management practiceby considering the presence of unburnt individuals in some fuel complexes. Numerous studies by Trabaud (Trabaud, 1970, 1980, 1983, 1989,1991; Trabaud and Lepart, 1981) on post-fire fuel dynamics show that six years are required for Quercus coccifera garrigue to recover entirely. In the present study, Kermes oak was a dominant species of the various garrigues and was also present in the understorey of most of the forest types (Table 
1 1). For this reason, fuel build-up dynamics in all the selected plant communities (except

2 grassland, one stage) were analysed based on six annual stages:

- Stage C: corresponding to the control and where the plant community was stable at its maximum phytovolume.

- Stage 1: representing the fuel one year after prescribed burning.

- Stages 2 to 5: representing the fuel 2 to 5 years after prescribed burning, respectively. Grassland was considered only at the control stage because the vigorous post-fire dynamics of Brachypodium retusum meant that the entire herbaceous phytovolume was recovered in the year following the treatment (Dureau, 2003).

Fuel complexes were generated for the various stages of the plant communities based on coupled approaches (Table 2):

- Phytovolume evolution after treatment from phytovolume data collected in fuel break areas (2003-2006) where prescribed burning was applied;

- documented post-fire recovery data for the understorey of Pinus halepensis forest and kermes oak garrigue, from the scientific literature (e.g. Trabaud, 1985, 1991; Trabaud and Lepart, 1981; Koukoura 1987 ; Sala and Sabate 1987 ; Cañellas and San Miguel 2000; Dureau et al. 2003)

- expert appraisal, particularly to take account of the proportion of unburnt fuel during the treatment.

These approaches involved an assessment of the typical properties required to describe the dynamics of each fuel complex, e.g. species presence and its physiological status (unburnt: live material; burnt: dead material; resprout: new live shoots after burning), together with the height and cover fraction of each species (Table 1 and 2).

[Table 2]

\subsection{Description of the different fuel complexes in FIRETEC}

In FIRETEC, fuel is described by means of three main input data: bulk density $\rho\left(\mathrm{kg} \cdot \mathrm{m}^{-3}\right)$, area per volume ratio $\sigma\left(\mathrm{m}^{-1}\right)$, and fuel moisture content $M C(\%)$. These variables are represented on a three dimensional mesh with resolution of about $2 \mathrm{~m}$ that results in fuel distribution near the ground generally being under-resolved. To reduce the inaccuracies induced, a fourth variable corresponding to actual fuel height in the shrub layer, is introduced. 
1 This is used to improve the computation of both flow movement and radiative transfer in

2 shrubland, based on a more realistic geometry (Pimont, 2008). A simple fuel editor is used to 3 build these four, three-dimensional arrays required for the fuel description in FIRETEC 4 (Pimont, 2008), and is based on certain stand parameters and physical properties. Horizontal 5 heterogeneous patterns are randomly assessed for each species based on cover fraction $(C$ in $\%)$ and mean clump size ( $L$ in $\mathrm{m})$. Vertical fuel distribution takes account of species height (h in $\mathrm{m}$ ) and crown base height (cbh in $\mathrm{m}$ ). In our study, heights and cover fractions for trees, shrubs and herbaceous species at the various post-fire stages were assessed by the three approaches described previously (see paragraph 2.3 and Tables 1 and 2), together with crown base height. The mean bulk density of each species (given its height and status: unburnt, resprout or burnt) was assessed from fuel databases (DBClump and DBparticles, http://www.eurifirestar.org/index.php). Only the physical characteristics of fine fuels (leaves and twigs $<2 \mathrm{~mm}$ ) were considered to compute bulk density because thicker materials are generally not involved in the combustion process at the fire front (Table 3) (Rothermel, 1983). With regard to burnt individuals, only remaining fine twigs were taken into account. The area to volume ratio for each species was computed from the database (DBClump). The last variable required was the moisture content of each species, given its status. $P$. halepensis and B. retusum moisture content was determined from the literature (Caraglio et al., 2005; Cohen and Deeming, 1985; Dimitrakopoulos et al, 2007). A multi-annual regional field survey (http://reseau-hydrique.org/) was used for the other species. Values were expressed as moisture content for live fuels and ranged from $66 \%$ to $100 \%$ during the summer. Moisture content for dead material was considered to be $20 \%$ in the case of burnt $R$. officinalis skeleton.

[Table 3]

From this description of the various fuel complexes, the total fuel load was calculated and then distributed spatially for each vegetation scenes analyzed in FIRETEC.

\subsection{Fire simulations}

The aim of the study was to compare the combustibility of 43 cases ( 7 fuel complexes at 6 different stages, and grassland). As this represents a significant computational cost, we used two procedures to save computational time: (i) we defined initial wind flow conditions before 
1 fire ignition, together with boundary conditions based on empirical laws, and (ii) we used

2 cyclic lateral boundary conditions during fire propagation simulations.

4 Empirical laws were used to set initial flow conditions before fire ignition and establish upwind and downwind boundary conditions. These laws are based on wind profiles that depend on the Leaf Area Index (LAI) of the stand (Raupach, 1994; Su et al., 1998), and are described in Appendix A. This avoided any precomputation of ambient wind based on Large Eddy Simulation (LES), which can accurately compute the flows within and above heterogeneous canopies, but which also has a very significant computational cost (Pimont et al., 2009). Ambient wind flow was considered to be in equilibrium with the canopy, which means that transitions between fuel types were neglected. The wind was blowing along the $\mathrm{x}-$ axis and with a reference value at $40 \mathrm{~m}$ height above ground $U_{40}^{2 m b}$ of $10 \mathrm{~m} . \mathrm{s}^{-1}$.

It is noteworthy that the same geostrophic ambient wind was used for all the simulations but the wind at 2 or $6 \mathrm{~m}$ height could be very different depending on the vegetation, being far lower in dense canopies than in light shrublands. This part of the methodology was crucial as it guaranteed an objective comparison of the different stages and complexes under the same ambient conditions which is never the case in field experiments or in modelling when fuel effects are not explicitly taken into account in the flow computation.

The use of cyclic lateral boundary conditions in the y-direction was the other approach adopted to save computational time. It means that the physical system behaved in exactly the same manner on both lateral sides of the domain. Such a configuration was used to simulate an infinite fire line. Computations were still three-dimensional in this solution, but allowed us to reduce the number of cells along the y-axis, saving computational time and reproducing accurately behaviour of large wildfires (Linn et al., 2010). In terms of fire behaviour, the consequence of these assumptions is that the simulations of the present study deal with large fires (more than $100 \mathrm{~m}$ wide) that should be seen as "worse case" scenarios. However, head fires arriving on fuel-breaks might be much narrower (due to local topography, wind and fire history). In this case, fire intensity and spread rates will be much lower that in our study, because fire width affects a lot the spread, especially below $50 \mathrm{~m}$ (Cheney et al., 1998; Linn et al., 2005a; Linn et al. 2010). 
1 The computational domain was represented on a three-dimensional $320 \mathrm{~m} \times 40 \mathrm{~m} \times 615 \mathrm{~m}$ 2 grid (Fig. 2), with a horizontal resolution of 2 meters. The use of only 20 cells along the y axis 3 was rendered possible through the use of cyclic lateral boundary conditions. The mesh was 4 stretched in the vertical direction, starting from $1.5 \mathrm{~m}$ resolution near the ground up to $40 \mathrm{~m}$ at 5 the top of the domain $(615 \mathrm{~m})$. This resolution was sufficient to represent clumps larger than $62 \mathrm{~m}$ wide. The fire line was ignited at $\mathrm{x}=80 \mathrm{~m}$.

[Fig. 2]

Additionally, the vertical profile of potential temperatures was constant at $300 \mathrm{~K}$ (neutral atmosphere), and the atmosphere was dry. A $0.01 \mathrm{~s}$ time step was used.

Fire behaviour was analysed on the basis of ROS, computed from the position of isosurface $600 \mathrm{~K}$, and intensity, computed from predicted fuel consumption, using Byram's law. Mean ROS and intensity data were computed over the period during which the fire was located in the $100 \mathrm{~m}$ long area located between $\mathrm{x}=140$ and $240 \mathrm{~m}$ (Fig. 2). This of course was possible only when the fire spread over the entire domain; when it stopped after a few meters of propagation, initial ROS and intensities where estimated (derived from the first half distance gone over by the fire, before the slow down preceding extinction).

\section{Results}

\subsection{Standing fuel load and fuel build-up after prescribed burning}

The total fuel load (Fig. 3) of untreated woody plant communities ranged between 8.2 and 14.5 t.ha ${ }^{-1}$. The highest values were found in Pure pine and Dense oak coppice stands, both having the highest canopy closure (50\%), with 14.5 t.ha $^{-1}$ and 13.0 t.ha $^{-1}$ respectively. A mean value of $11.4 \pm 0.33$ t.ha ${ }^{-1}$ characterized partly closed Mixed oak-pine, as well as Sparse oak coppice and high garrigue (Holm oak garrigue and Kermes oak garrigue). The low Mixed garrigue had the lowest load of all woody communities with 8.2 t.ha $^{-1}$.

Prescribed burning reduced total fuel load by at most $50 \%$ in closed to partly closed forest stands where the mean annual increase in phytomass was calculated to be $1.2 \mathrm{t}^{-\mathrm{ha}^{-1}}$ in the first 
1 years after burning (Fig. 3). Phytomass stabilized after 4 years in pine stands (Pure pine stand 2 and Mixed oak-pine) and after only 3 years in Dense oak coppice. In all open ecosystems 3 (including Sparse oak coppice), prescribed burning reduced total fuel load by more than 50\% 4 (between 54 and 78\%) one year after treatment, but these plant communities showed a 5 considerable mean annual increase in phytomass of about $2.3 \mathrm{t}^{-h a^{-1}}$ over the first three post6 treatment years. Total phytomass thus began to stabilize at stage 3. Phytomass growth 7 dynamics in Mixed garrigue was lower with a mean annual phytomass increase of 1 t.ha $^{-1}$ 8 over the first three years.

10 Brachypodium retusum grassland was insensitive to prescribed burning and its total 11 phytomass was estimated to be $1.1 \mathrm{t}^{\mathrm{ha}} \mathrm{a}^{-1}$.

[Fig. 3]

Shrub fuel loads (Tables 1 and 2) were calculated as the sum of the phytomass less than $2 \mathrm{~m}$ in height. Results showed similar trends to those noted for total fuel load. Shrub fuel load was reduced by 46,53 and $62 \%$ in the three forest stands in the first year after prescribed burning. The phytomass recovered by more than $80 \%$ in 4 years for pine stands and 3 years for Dense oak coppice. The fuel load decrease in all garrigues and Sparse oak coppice ranged between $56 \%$ and $84 \%$ the year after the prescribed burning. They required three years to recover $70 \%$ of their initial phytomass.

\subsection{Wind profiles computed by FIRETEC}

FIRETEC solves Navier-Stokes equations and includes a drag and turbulence model to compute wind around and within a given type of vegetation (Fig. 4). Graphs represent the typical wind profiles obtained in the different fuel complexes with no treatment. It is noteworthy that for the same ambient wind $\left(10 \mathrm{~m} \cdot \mathrm{s}^{-1}\right.$ at $40 \mathrm{~m}$ high), the wind profiles in and above the fuel were completely different, with a far higher wind velocity above the grassland or the garrigues, than within pine stands or Dense oak coppice.

\subsection{Global analysis of fire behaviour}


2 As a general rule, fire intensity in the different plant communities was significantly lower in 3 the first two years after prescribed burning (stage 1 and 2) than in the control (Table 4). The 4 fire also stopped in the early stages after burning, except in Mixed garrigue. High forest stands (Pure pine stand and Mixed oak-pine) were generally characterized by lower rate of spread (for the same ambient wind) than in lower plant communities, due to a marked reduction in wind velocity at ground level (Table 5). Prescribed burning in these plant communities greatly reduced fire intensity for 3 years after treatment. In lower oak coppices forest stands and Kermes oak and Mixed garrigues, the effects of prescribed burning were highly significant only for the first two years after treatment.

[Table 5]

Table 6 outlines the distances covered by the fire in fuel complexes where the fire was not sufficiently intense to cross the entire domain. The fuel reduction in the shrub strata by prescribed burning led to fire extinction up to 3 years after treatment in Aleppo pine forest stands (Pure pine stands and Mixed oak-pine) whereas this effect lasted only one year in oak forest types (Dense and Sparse oak coppices) and oak shrublands (Holm oak garrigue and Kermes oak garrigue). Fire propagation did not exceed $32 \mathrm{~m}$ (highest value found in Dense oak coppice) in the first year after prescribed burning. In Mixed oak-pine stands, the presence of Holm oak trees added fuel in the shrub layer compared to Aleppo pine stands, and this impacted on fire propagation.

\subsection{Complexes by simulation results}

\subsubsection{Pine stands: Pure pine stand and Mixed oak-pine}

The Pure pine and Mixed oak-pine stands showed similar fire behaviour. Fire intensity was low for the first two years after treatment, with values ranging between 1300 and $1500 \mathrm{~kW} . \mathrm{m}^{-}$

\footnotetext{
${ }^{1}$ for Pure pine stand and values between 600 and $730 \mathrm{~kW} \cdot \mathrm{m}^{-1}$ for Mixed oak-pine. At stage 3,
} 
1 fire intensity increased to $2000 \mathrm{~kW} . \mathrm{m}^{-1}$ and $2300 \mathrm{~kW} \cdot \mathrm{m}^{-1}$, respectively, while it reached 2 between 5500 and $6000 \mathrm{~kW} \cdot \mathrm{m}^{-1}$ in stages 4 and 5, as well as in the control. It should be 3 noticed in this case that intensity can be a little lower in the control $(5500 \mathrm{~kW} . \mathrm{m}-1)$, than in 4 stage 4 and 5. This was explained by lower rate of spread in the control. ROS values in the 5 Pure pine stand were lower than in Mixed oak-pine, even four years after prescribed burning 6 with a mean ROS of $0.37 \mathrm{~m} \cdot \mathrm{s}^{-1}$ compared to $0.45 \mathrm{~m} \cdot \mathrm{s}^{-1}$ in the mixed stand. In both plant communities, extinction in the earlier stages can be explained by the wind reduction at ground 8 level due to drag. This also explains their ROS values that were generally lower than in the 9 garrigues for the same ambient wind (Fig. 5a).

\subsubsection{Dense oak coppice}

12 In Dense oak coppice, the fire spread in all stages except one year after burning, where the 13 fire covered $32 \mathrm{~m}$ before it stopped. Fire intensity increased from a low level (less than 2000 $\mathrm{kW} \cdot \mathrm{m}^{-1}$ ) for stages 1 and 2 , to a very high level (more than 13,000 $\mathrm{kW} \cdot \mathrm{m}^{-1}$ ) for stages 3 to 5 and for the control. Stages 1 and 2 were also characterized by partial combustion of the domain (Fig. 5b) and ROS values were considerably lower than those for the other stages (Table 5). It is noteworthy that prescribed burning did not result in a major reduction in fuel cover fraction or load because the large Holm oak did not burn well in the winter season. This resulted in a high fuel load and very high combustibility in the latest stages. The reason for the significant threshold between stage 2 and 3 could not be fully elucidated based on fuel characteristics.

\subsubsection{Sparse oak coppice and Holm oak garrigue}

The fire in Sparse oak coppice and Holm oak garrigue spread in all stages except one year after burning and in this case covered $24 \mathrm{~m}$ and $12 \mathrm{~m}$, respectively (Fig. 5c). Fire intensity increased from a low level (less than $1000 \mathrm{~kW} \cdot \mathrm{m}^{-1}$ and $1600 \mathrm{~kW} \cdot \mathrm{m}^{-1}$ ) in stages 1 and 2, to high levels (more than $8000 \mathrm{~kW} \cdot \mathrm{m}^{-1}$ and $6400 \mathrm{~kW} \cdot \mathrm{m}^{-1}$ ) in stages 3 to 5 and for the control. This behaviour was consistent with the biomass pattern that was very low for stages 1 and 2 (between 2.5 and 4.4 t.ha $^{-1}$ ) but far higher for stages 3 to 5 and the control (between 7.2 and 11.5 t.ha $^{-1}$ ). This resulted in a fire behaviour threshold between stages 2 and 3. ROS values in stages 1 and 2 were also considerably lower than those in the other stages (Table 5). It should 
1 be noted that ROS values decreased between stage 3 and stage 5 and were lower in the

2 control. The fastest fire was obtained for stage 3 and here was about $40 \%$ faster than that in

3 the untreated case.

\subsubsection{Kermes oak garrigue}

6 The fire in Kermes oak garrigue spread in all stages except one year after burning and in this case covered $30 \mathrm{~m}$ before stopping (Fig. 5d). Fire intensity increased from a low level (less than $\left.900 \mathrm{~kW} \cdot \mathrm{m}^{-1}\right)$ in stage 1 and a moderate level in stage $2\left(3600 \mathrm{~kW} \cdot \mathrm{m}^{-1}\right)$, to a high level (more than $5400 \mathrm{~kW} \cdot \mathrm{m}^{-1}$ ) in stages 3 to 5 and in the control (no treatment). ROS values ranged between 0.32 and $0.43 \mathrm{~m} . \mathrm{s}^{-1}$. The fastest fire was obtained for stage 2 (Table 5). ROS values decreased between stage 2 and stage 5 and were lower in the control.

\subsubsection{Mixed garrigue}

14 The fire in Mixed garrigue spread in all stages, even one year after burning. But, it is noteworthy that the fire propagated erratically and did not burn the entire domain in this case, or in stage 2. Fire intensity increased from a low level (less than $1500 \mathrm{~kW} . \mathrm{m}^{-1}$ ) in stage 1 and a moderate level in stage $2\left(3300 \mathrm{~kW} \cdot \mathrm{m}^{-1}\right)$, to a high level (more than $\left.5700 \mathrm{~kW} \cdot \mathrm{m}^{-1}\right)$ in stages 3 to 5 and in the control (no treatment). ROS values ranged between 0.35 and $0.6 \mathrm{~m} . \mathrm{s}^{-1}$ (Table 5). The fastest fires were obtained for stages 2 to 4 , and were relatively fast for shrubland fires. It should be noted in this case that a significant amount of dead rosemary remained after prescribed burning, with a low moisture content.

\subsubsection{Grassland}

24 Fire intensity in the grassland fuel complex was as low as the lowest fire intensity recorded for the Sparse oak coppice fuel complex 2 years after prescribed burning $\left(900 \mathrm{~kW} . \mathrm{m}^{-1}\right)$, while fire rate of spread was the highest $\left(0.82 \mathrm{~m} . \mathrm{s}^{-1}\right)$ of all the fuel types tested.

\section{Discussion}

In our study, fuel load was reduced in the various plant communities by about $50-60 \%$ in dense stands and $60-80 \%$ in sparse ecosystems in the first year after treatment. Our study therefore showed that prescribed burning did not reduce fuel loads by the $75-80 \%$ threshold 
1 less marked fuel reduction is a good compromise between a total fire risk mitigation objective

2 and vegetation management for nature conservation, which is the secondary objective pursued 3 by managers of the Luberon State forest. A vegetation mosaic created by juxtapositioning 4 burnt (by prescribed burning) and unburnt patches is favorable to wildlife (Pons et al., 2003).

$6 \quad$ Prescribed burning therefore results in a very heterogeneous fuel structure, with patches of unburnt fuel, low resprouters and clumps of trees. It is very difficult to evaluate fire behaviour in this context and only a model that accurately represents the three-dimensional fuel structure has any hope of doing so. This is the case with FIRETEC and the reason why the model is appropriate for such a study. However, due to certain assumptions made in the combustion model (particularly the fact that there is no transport of pyrolysis product, which is burnt locally), the model should not be run with a grid cell size of less than two meters. With this resolution, some of the clumps of unburnt and resprouting fuel are merged, as are some small areas with no vegetation. For this reason, FIRETEC tends to represent fuel with small-scale heterogeneities in a more continuous manner than in reality. Some investigations into radiative transfer (Pimont et al. 2010) have already shown that small-scale heterogeneities may affect fire behaviour and tend to reduce its rate of spread. It is likely that the spatial resolution in FIRETEC causes fire intensity to be overestimated, particularly in cases where heterogeneity is small compared to grid cell size. In our study we questioned on which heterogeneity would be responsible of the threshold between stage 2 and stage 3 in the Dense oak coppice compared to the grid cell size. The increase in fuel phytomass with a high cover fraction in stage 3 (cover of 60\%) can explain the increase in fire intensity. However, we can also hypothesize that in addition areas with no vegetation, reduced by half between the two stages, were merged according to the low resolution of the model and therefore could not be taken into account adequately. Another limitation stemming from model resolution is seen when the fire stops, mostly in stage one. This FIRETEC prediction means that a fire will not propagate through convection and radiation under these conditions. But, the model does not take account of the small-scale conduction processes that might make a fire propagate in the field. Thus, caution should be exercised when the model predicts fire extinction.

Our results showed that the corresponding immediate reduction in fire line intensity ranged from $75 \%$ to $95 \%$. This is similar to the post-treatment reduction in fire line intensity found after different prescribed burning programmes, where values ranged from $80 \%$ to $98 \%$ (Fernandes et al., 1999; Rego et al., 1987). And although the Wade and Lunsdord (1989) 
1 thresholds were not reached, burning efficiency was satisfactory in the first year after

2 treatment.

3 The prescribed burning return interval for each plant community can be calculated by

4 comparing our results with a classification of fire line intensity (Hough and Albini, 1978;

$5 \quad$ Hirsch and Martell, 1996; Lampin-Cabaret et al., 2002). The $3500 \mathrm{~kW} \cdot \mathrm{m}^{-1}$ threshold has been

6 used to differentiate between i) low $\left(<1700 \mathrm{~kW} \cdot \mathrm{m}^{-1}\right)$ and moderate $\left(1700-3500 \mathrm{~kW} \cdot \mathrm{m}^{-1}\right)$ fire

7 intensities - which are still controllable by fire fighters - and ii) high (3500-7000 kW.m $\left.{ }^{-1}\right)$ and

8 very high $\left(>7000 \mathrm{~kW} . \mathrm{m}^{-1}\right)$ fire intensities that are beyond the control of fire fighters. The

9 present study therefore showed that prescribed burning was efficient for 2 years in most of the

10 Mediterranean plant communities analysed (fire intensities below the $3500 \mathrm{~kW} \cdot \mathrm{m}^{-1}$ threshold

11 value). After this stage, all forests and shrublands were highly combustible with a fire line

12 intensity that exceeded $5000 \mathrm{~kW} . \mathrm{m}^{-1}$ except for pine stands with or without Holm oak

13 (medium intensity of $2000 \mathrm{~kW} \cdot \mathrm{m}^{-1}$ at stage 3 ).

Mediterranean communities are recognized as highly fire resilient thanks to autosucession processes involving resprouter and obligate seeder species (Pausas, 2006; Pausas and Verdu, 2005). In the present study, the shrub strata of the plant communities were dominated by two resprouter species, $Q$. coccifer $a$ and $Q$. ilex, which explained the short post-fire vegetation recovery time. The ability of these species to rapidly mobilize underground reserves (water, nutrients, carbohydrates) for new sprouts (Pausas, 2001) allows the plant cover to recuperate in the first few years after a fire (Trabaud, 1974; Trabaud, 1985). In eastern Spain, only 3.5 years were required after a wildfire for a $Q$. coccifera garrigue to return to its pre-fire condition (Delitti et al., 2005). In France, several studies (Bertrand et al., 1991; Rigolot, 1997; Trabaud, 1974; Trabaud, 1991) have shown that between 2 and 7 years are necessary for $Q$. coccifera phytomass or phytovolume to recover after prescribed burning. In the present study we considered that plant communities recovered more than $60 \%$ of their phytomass 3 years after treatment, even though a series of burning treatments in several plots of the same plant community may lead to different fuel reduction levels (Fernandes et al., 2000). Low fire line intensity $\left(900 \mathrm{~kW} \cdot \mathrm{m}^{-1}\right)$ was obtained for grassland which is entirely independent of the treatment since the resprouter hemicryptophyte, Brachypodium retusum, is highly resilient to fire (Baeza and Vallejo, 2008; Caturla et al., 2000).

Fuel load accumulation therefore greatly influences the behaviour and intensity of a fire, and some specific residual fuel has a particularly marked impact. 
1 Fuel load recovery in the shrub strata and FIRETEC intensity predictions were fairly sensitive

2 to the presence of $Q$. ilex. This can be explained by the distribution of a part of the phytomass

3 below $2 \mathrm{~m}$ in height (even reaching the ground for some individuals) and that was not

4 consumed during prescribed burning. This residual fuel load rapidly induced vertical fuel

5 continuity between Holm oak trees and shrub layers, resulting in crown fire. Regarding $Q$.

6 ilex plant communities, the dense cover provided by oak trees $(50 \%)$ in the Dense oak

7 coppice explained its very rapid fuel load recovery (more than $65 \%$ only 2 years after

8 treatment). But, fire intensity was significantly reduced $\left(<2000 \mathrm{~kW} . \mathrm{m}^{-1}\right)$ in the early post-fire

9 years due to sufficient horizontal and vertical heterogeneity.

10 The two garrigues also showed different fire behaviours. Despite a lower fuel load in the

11 Mixed garrigue, the presence of burnt $R$. officinalis in the fuel complexes contributed to

12 higher fire propagation at all stages. The production or retention of dead material is the most

13 critical factor in explaining a greater or lesser susceptibility to fire (Baeza et al., 2006). Burnt

14 R. officinalis, which does not resprout as an obligate seeder species, holds up in prescribed

15 burning areas in the form of dead skeletons devoid of leaves but not the fine fuel fraction 16 composed of twigs (own observations). A substantial quantity of standing necromass is thus 17 maintained in post-fire Mixed garrigue, resulting in high flammability.

According to our results, tree canopy also plays a significant role in fire behaviour. Fire

propagation was twice to three times faster in Kermes oak garrigue than in Pure pine stands in the first three years after treatment, whereas fuel shrub composition was very similar. Pure pine stands were associated with a lower shrub load than the garrigue, but the main reason for the lower ROS in fuel complexes involving trees is that wind speed decreases at ground level under tree canopy (Shaw et al., 1988; Lee, 2000). Less fuel and low wind under pine trees even led to fire extinction in the earlier stages, showing that prescribed burns are more effective under tree canopy than in garrigue. These results also confirm the advantages of maintaining a proportion of canopy cover in fuel-break management. Pimont et al. (2010) have shown that $25 \%$ canopy cover in a Pinus halepensis stand significantly reduced fire intensity in comparison with a closed stand. These authors also noted a less inclined plume 30 and a lower firefront temperature than in open fuel breaks, and this is a crucial point in fire 31 fighting.

\section{Conclusion}


1 This work has generated useful data that help in the current need to characterize and classify

2 Mediterranean fuels in relation to their potential fire behaviour. All 8 common fuels described

3 (Control stages) in limestone Provence were highly combustible and their derivated fuel

4 complexes provided valuable information on the effects of prescribed burning on immediate

5 reduction in potential fire hazard and the effect of time since burning.

7 In this study, the spatial distribution of fuels before treatment was heterogeneous, but fuel 8 modifications following the burn of a plot were applied in a homogeneous way and in the 9 same way within plots of the same plant community. We must, in the future, take account of 10 the fact that in reality, fuel consumption by prescribed burning within a plot is generally very variable (Robichaud and Miller, 1999) and a series of burning treatments in several plots of the same plant community may lead to different fuel reduction rates (Fernandes et al., 2000).

In conclusion this study identified useful information for prescribed burners, i.e. the fire behaviour and the temporal thresholds related to prescribed burning effectiveness in the reduction of fuel hazard in the different fuel complexes. However, to make recommendations to plan fuel treatment at the landscape scale the spatial distribution of the fuel complexes and their implication in the fire risk will be necessary.

\section{Acknowledgements}

This study was partially funded by the European Commission as part of the FIREPARADOX research programme (contract FP6-018505), and we wish to thank Los Alamos National Laboratory Institutional Computing Resources for the computations involved in this study.

Appendix A. Empirical mean profile used to establish initial and boundary conditions in FIRETEC for the present study.

31 Fuel characteristics in each plot were used to compute a mean LAI for the stand:

Eq. (A.1) $\quad L A I=\frac{1}{2 l_{x} l_{y}} \int_{0}^{h \max } \int_{0}^{l y} \int_{0}^{l x} \frac{\rho}{\rho_{\text {wood }}} \sigma d x d y d z$

$33 l_{x}$ and $l_{y}$ the horizontal dimensions of the domain along the $x$ and $y$ axes, and hmax the 
Version définitive du manuscrit publié dans / Final version of the manuscript published in : Ecological Modelling, 2011, vol.222, no.8, DOI: 10.1016/j.ecolmodel.2011.02.004

1 maximum height of the fuel bed. $\rho, \rho_{\text {wood }}$ and $\sigma$ are the bulk density, wood density and area

2 to volume ratio of the fuel, respectively.

3 A typical wind velocity profile $\hat{u}(z)$ was computed, according to Raupach et al. (1994) and

4 Su et al. (1998):

$5 \quad$ Eq. (A.2) if $z \leq h \max , \hat{u}(z)=\exp \left(-c 4\left(1-\frac{z}{h \max }\right)\right)$

$6 \quad$ Eq. (A.3) if $z \geq 2 h \max , \hat{u}(z)=\frac{c l}{\kappa} \ln \left(\frac{1}{c 3}\left(\frac{z}{h \max }+c 2-1\right)\right)$

7 if $\mathrm{z}$ is between $h \max$ and $2 h \max$, a regression was made between $\hat{u}(h \max )$ and $\hat{u}(2 \mathrm{hmax})$ 8

9 Eq. (A.4)

$$
c l=\frac{u *}{U_{h}}=\min (\sqrt{0.003+0.15 L A I}, 0.3)
$$

Eq. (A.5)

$$
c 2=1-\frac{d}{h}=\frac{1-\exp (-\sqrt{7.5 L A I})}{\sqrt{7.5 L A I}}
$$

11 Eq. (A6)

$$
c 3=\frac{z 0}{h}=c 2 \exp \left(-\frac{\kappa}{c l}-\ln (2)+0.5\right)
$$

12 Eq. (A.7)

$$
c 4=\max \left(\min \left(\frac{3.2-1.7}{4-1}(L A I-1)+1.7 ; 3.2\right) ; 1.7\right)
$$

13

14 Ambient wind flow was then considered in equilibrium with the canopy. Its direction was parallel to the $\mathrm{x}$ axis and it was defined as follows:

16 Eq. (A.8)

$$
u^{a m b}(x, y, z)=u_{40}^{a m b} \frac{\hat{u}(z)}{\hat{u}(40)}, \quad v^{a m b}(z)=w^{a m b}(z)=0
$$

17 where the upper script amb indicates the ambient value. The ambient wind velocity $U_{40}^{\text {amb }}$ at $40 \mathrm{~m}$ above ground level was $10 \mathrm{~m} . \mathrm{s}^{-1}$. This ambient wind flow was used to initiate the flow and to assess the upwind and downwind boundary conditions of the domain through a relaxation process. 
1

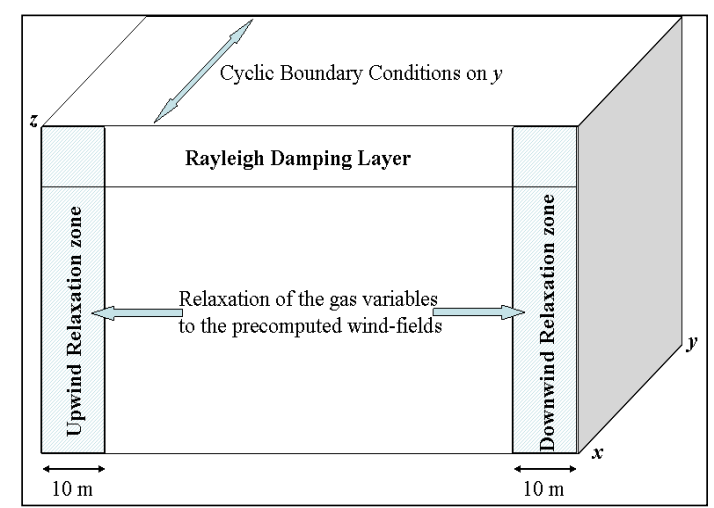

\section{Schematic representation of boundary conditions on the computational domain}

Table Abreviation and symbols

\begin{tabular}{|l|l|}
\hline hmax & maximum fuel bed height \\
\hline$L A I$ & leaf area index \\
\hline$l_{x}, l_{y}$ & horizontal dimensions of the domain \\
\hline$\rho$ & fuel bulk density $(\mathrm{kg} / \mathrm{m} 3)$ \\
\hline$\rho_{\text {wood }}$ & fuel bulk density $(\mathrm{kg} / \mathrm{m} 3)$ \\
\hline$\sigma$ & volume ratio of the fuel $(1 / \mathrm{m})$ \\
\hline$\hat{u}(z)$ & normalized wind profile $(\hat{u}(h \max )=1)$ \\
\hline
\end{tabular}

\section{References}

Agee JK, Bahro B, Finney MA, Omi PN, Sapsis DB, Skinner CN, van Wagtendonk JW, Weatherspoon CP. The use of shaded fuelbreaks in landscape fire management. Forest Ecology and Management 2000; 127(1-3): 55-66.

Baeza M, Raventós J, Escarré A, Vallejo V. Fire Risk and Vegetation Structural Dynamics in Mediterranean Shrubland. Plant Ecology 2006;187(2): 189-201.

Baeza MJ, Vallejo VR. Vegetation recovery after fuel management in Mediterranean shrublands. Applied Vegetation Science 2008; 11(2): 151-158.

Beylier B, Kmiec L, Etienne M. Une coupure de combustible en Luberon. Bilan de douze ans de suivis pastoralistes, DFCI et environnementaux. Réseau Coupures de CombustibleÉd. de la Cardère Morières ; 2006.

Bertrand M, Etienne M, Gillon D, Legrand C, Lumaret JP, Rigolot E, Valette JC. Prévention des incendies de forêt en région méditerranéenne par utilisation du feu et du paturâge contrôlés: impact sur l'écosystème forestier. Rapport final - sous projet II; contrat EVAV-0088-F(CD) avec la C.E.E; responsable Castri di F ; 1991.

Burgan R, Rothermel R. BEHAVE: fire behavior prediction and fuel modeling system FUEL subsystem. USDA Forest Service, Ogden ; 1984.

Cañellas, I. San Miguel, A. Biomass of root and shoot systems of Quercus coccifera shrublands in Eastern Spain. Annals of Forest Science 2000; 57 (8), p 803-810.

Caraglio Y, Pimont F, Rigolot E. Pinus halepensis Mill Architectural Analysis for Fuel Modelling. In: V. Leone, Lovreglio. MEDPINE 3 Conservation, regeneration and restoration of mediterranean pines and their ecosysems. Bari, CIHEAM, 2007.

Caturla RN, Raventos J, Guardia R, Vallejo VR. Early post-fire regeneration dynamics of 
Brachypodium retusum Pers. (Beauv.) in old fields of the Valencia region (eastern Spain). Acta Oecologica-International Journal of Ecology $2000 ; 21(1): 1-12$.

Cheney N, Gould J, Catchpole W. Prediction of fire spread in grasslands. International Journal of Wildland Fire 1998; 8(1): 1-13.

Cohen, Jack D.; Deeming, John E. The National Fire-Danger Rating System: basic equations. Gen. Tech. Rep. PSW-82. Berkeley, CA: Pacific Southwest Forest and Range Experiment Station, Forest Service, U.S. Department of Agriculture; 1985.

Delitti W, Ferran A, Trabaud L, Vallejo VR. Effects of fire recurrence in Quercus coccifera L. shrublands of the Valencia Region (Spain): I. plant composition and productivity. Plant Ecology 2005; 177(1): 57-70.

Dimitrakopoulos AP., Mitsopoulos ÆID., Raptis ÆDI. Nomographs for predicting crown fire initiation in Aleppo pine (Pinus halepensis Mill.) forests. European Journal of Forest Research 2007; $126: 555-561$.

Dupuy JL, Morvan D. Numerical study of a crown fire spreading toward a fuel break using a multiphase physical model. International Journal of Wildland Fire 2005; 14(2): 141151.

Dureau R (coord.). Gestion des garrigues à chêne kermès sur coupures de combustible. Réseau Coupures de combustible - Éd. de la Cardère Morières; 2003.

Etienne M. Legrand C. Armand D. Stratégie d'occupation de l'espace par les petits ligneux après débroussaillement en région méditerranéenne française. Exemple d'un réseau de pare-feu dans l'Estérel. Ann. Sci. For. 1991; 48: 667-677.

Etienne M, Rigolot E. Méthodes de suivi des coupures de combustible. Réseau Coupures de combustible - Éd. de la Cardère Morières; 2001.

FAO and GFMC. Wildland Fire Management Terminology. On-line update of the first edition of 1986: http://www.fire.uni-freiburg.de/literature/glossary.htm.; 2003

Fernandes P, Botelho H. A review of prescribed burning effectiveness in fire hazard reduction. International Journal of Wildland Fire 2003; 12: 117-128.

Fernandes P, Botelho H, Bento J. Prescribed fire to reduce wildfire hazard: an analysis of management burns in Portuguese pine stands. In: CINAR (Editor), DELFI International symposium on forest fires: needs and innovations, Athens; 1999. p. 360364.

Fernandes P, Botelho H, Loureiro C. Modelling the links between environmental conditions, fire behavior and fire effects important for prescribed burning operational purposes. Fire Torch Project Contract No. ENV4-CT98-0715, Deliverable F1; 2000.

Finney M. Design of regular landscape fuel treatment patterns for modifying fire growth and behavior. Forest Science 2001; 47(2): 219-228.

Finney MA, Selia RC, McHugh CW, Ager AA, Bahro B, Agee JK. Simulation of long-term landscape-level fuel treatment effects on large wildfires. International Journal of Wildland Fire 2007; 16: 712-727.

Finnigan J. Turbulence in plant canopies. Annual review of fluid mechanics 2000; 32: 519571.

Green LR. Fuelbreaks and other fuel modification for wildland fire control. USDA Agriculture handbook; 1977.

Hirsch KG, Martell DL. A review of initial attack fire crew productivity and effectiveness. International Journal of Wildland Fire 1996; $6: 199-215$.

Houg WA, Albini FA. Predicting fires behavior in Palmetto-Gallberry fuel complexes, USDA Forest Service General Technical Report SE-174, Ashevill, NC; 1978.

Koukoura, Z. 1987. Light Intensity effects on dynamic growth of kermes oak (Quercus coccifera L.). Ecologia Mediterranea, Tome XIII (fascicule 3), p 19-25.

Lampin-Cabaret C, Jappiot M, Alibert N, Manlay R. Prototype of an intensity scale for the 
natural hazard: forest fire. In: D.X. Viegas (Editor), Proceedings of IV International Conference on Forest Fire Research / 2002 Wildland Fire Safety Summit. Forest Fire Research \& Wildland Fire Safety, Coimbra, Portugal; 2002.

Lazaro A. Wise Fire Use Practices in Wildland Fire Management: An Overview of the European Situation, III International Symposium on Fire Economics, Planning and Policy: Common Problems and Approaches, April 29 - May 2, 2008, Carolina, Puerto Rico; 2008.

Lee X. Air motion within and above forest vegetation in non-ideal conditions. Forest Ecology and Management 2000; 135: 3-18.

Linn RR. A transport Model for Prediction of Wildfire Behavior, Sci. Rep. LA -13334-T, Los Alamos National Laboratory, Los Alamos, NM ; 1997.

Linn RR, Cunningham P. Numerical simulations of grass fires using a coupled atmospherefire model: basic fire behavior and dependence on wind speed. Journal of Geophysical Research, 110, D13107; 2005.

Linn RR, Canfield J, Winterkamp J, Cunningham P, Colman JJ, Edminster C, Goddrick SL. Numerical Simulations of Fires Similar to the International Crown Fire Modelling Experiment, Proceedings of the Sixth Symposium on Fire and Forest Meteorology. American Meteorological Society, Canmore, Alberta; 2005a.

Linn RR, Winterkamp J, Colman JJ, Edminster C, Bailey J. Modeling interactions between fire and atmosphere in discrete element fuel beds. International Journal of Wildland Fire 2005b; 14: 37-48.

Linn RR, Canfield JM, Cunningham P. Critical roles of three-dimensional atmosphere/fire coupling on fire behavior. Proceedings of the Eigth Symposium on Fire and Forest Meteorology. American Meteorological Society, USA, Kalispell; 2010.

Loureiro C, Fernandes P, Botelho H. Optimizing prescribed burning to reduce wildfire propagation at the landscape scale. In: Viegas (Editor), Forest Fire Research \& Wildland Fire Safety. Millpress, Rotterdam, Louso, Portugal; 2002. p. 9.

Marzano R, Bovio G, Guglielmet E, Camia A, Deshayes M, Lampin C, Salas J, Martinez J, Molina D, Geronimo N, Carrega P, Fox D, Sabaté S, Vayreda J, Martin P, Martinez J, Vilar L, Conese C, Bonora L, Tsakalidis S, Gitas I, Karteris M. Wildland Fire Danger and Hazards: a state of the art, final version; 2006.

Mell W, Jenkins MA, Gould J., Cheney N. A physics-based approach to modelling grassland fires. International Journal or Wildland Fire 2007; 16: 1-22.

Morvan D, Dupuy JL. Modeling of fire spread through a forest fuel bed using a multiphase formulation. Combustion and Flame 2001; 127 : 1981-1994.

ONF. Révision d'aménagement de la Forêt Domaniale du Luberon pour la période 20082022. Document d'aménagement forestier; 2008.

NIFC (National Interagency Fire Center) Prescribed fire statistics. URL: www.nifc.gov/stats/prescribedfirestats.html; 2001.

Parsons RA. Spatial variability in forest fuels: Simulation modeling and effects on fire behavior. Ph.D. Dissertation, University of Montana ; 2007.

Pausas J. Simulating Mediterranean landscape pattern and vegetation dynamics under different fire regimes. Plant Ecology 2006; 187(2): 249-259.

Pausas JG. Resprouting vs seeding - a Mediterranean perspective. Oikos 2001; 94(1): 193194.

Pausas JG, Verdu M. Plant persistence traits in fire-prone ecosystems of the Mediterranean basin: a phylogenetic approach. Oikos 2005; 109(1): 196-202.

Pimont F. Modélisation physique de la propagation des feux de forêts: Effets des caractéristiques physiques du combustible et de son hétérogénéité. Thesis, Université de la Méditerranée - Aix Marseille II, Marseille; 2008. 
Pimont F, Dupuy JL, Linn RR, Dupont S. Validation of FIRETEC wind-flows over a canopy and a fuel-break. International Journal of Wildland Fire 2009; 18: 775-790.

Pimont F, Dupuy JL, Linn RR, Dupont S. Impacts of tree canopy structure on wind-flows and fire propagation simulated with FIRETEC. Annals of Forest Science 2010; (in press)

Pons P, Lambert B, Rigolot E, Prodon R. The effects of grassland management using fire on habitat occupancy and conservation of birds in a mosaic landscape. Biodiversity and Conservation 2003, 12: 1843-1860.

Pyne SJ, Laven RD. Introduction to wildland fire. John Wiley and Sons, New York; 1996.

Raupach MR. Simplified expressions for vegetation roughness length and zero-plane displacement as function of canopy height and area index. Boundary Layer and Meteorology 1994; 71: 1-2.

Rego F, Silva JM, Botelho H. Prescribed burning in the reduction of wildfire hazard in Northern Portugal, World congress on wildfire prevention, Athens.; 1987.

Rigolot E. Etude sur la caractérisation des effets causés aux écosystèmes forestiers méditerranéens par les brûlages dirigés répétés. Exercice 1996, INRA, Unité de Recherches Forestières Méditerranéennes, Avignon; 1997.

Rigolot E. Fuel-break assessment with an expert appraisement approach. In: D.X. Viegas (Editor), 4. International Conference on forest fire research / 2002 Wildland fire safety summit. Millpress, Rotterdam (NLD); Luso (PRT); 2002.

Rigolot E, Castelli L, Cohen M, Costa M, Duché Y. Recommendations for fuel-break design and fuel management at the wildland urban interface: an empirical approach in south eastern France. In: T. Institute of Mediterranean Forest Ecosystems and Forest Products (Editor), Warm International Workshop, Athènes (GRC) ; 2004. p. 131-142.

Rigolot E, Alexandrian D. Learning from fuel-break behaviour during the 2003 larges fires in south eastern France. Forest Ecology and Management 2006 ; 234: 227.

Rigolot E, Fernandes P, Rego F. Managing wildfire risk: prevention, suppression. In: Y. Birot (Editor), Living with wildfires: what science can tell us. A contribution of the sciencepolicy dialogue. European Forest Institute, Joensuu (FIN) ; 2009. p. 49-52.

Robichaud PR, Miller SM. Spatial interpolation and simulation of post-burn duff thickness after prescribed burning. International Journal of Wildland Fire 1999 ; 9: 137-143.

Rothermel RC. How to predict the spread and intensity of forest and range fires. USDA Forest Service, Ogden ; 1983.

Sala, A. Sabate, S. Structure and organisation of a Quercus coccifera garrigue after fire. Ecologia Mediterranea 1987; tome XIII (fascicule 4), p 99-110.

Shaw RH, Den Hartog G, Neumann HH. Influence of foliar density and thermal stability on profiles of Reynolds stress and turbulence intensity in a deciduous forest. BoundaryLayer Meteorology 1988; 45: 391-409.

Sneeuwjagt R. Fighting fire with fire. Landscope 1994 ; 9(3): 23-27.

Stephens SL. Evaluation of the effects of silvicultural and fuels treatments on potential fire behaviour in Sierra Nevada mixed-conifer forests. Forest Ecology and Management $1998 ; 105: 21-35$.

Stephens SL, Moghaddas JJ. Fuel treatment effects on snags and coarse woody debris in a Sierra Nevada mixed conifer forest. Forest Ecology and Management 2005 ; 214: 5364.

Su HB, Shaw RH, Paw UKT, Moeng CH, Sullivan PP. Turbulent statistics of neutrally stratified flow within and above a sparse forest from large-eddy simulation and field observations. Boundary-layer Meteorology 1998 ; 88: 363-397.

Sullivan AL. Wildland surface fire spread modelling, 1990-2007. 1: Physical and quasiphysical models. International Journal of Wildland Fire 2009a ; 18 (4) : 349-368. 
Sullivan AL. Wildland surface fire spread modelling, 1990-2007. 2: Empirical and quasiempirical models. International Journal of Wildland Fire 2009b ;18 (4) : 369-386.

Trabaud L. Quelques valeurs et observations sur la phyto-dynamique des surfaces incendiées dans le Bas-Languedoc (premiers résultats), Naturalia monspeliensia, sér. Bot. 1970 ; $21: 231-242$.

Trabaud L. Experimental study on the effects of prescribed burning on a Quercus coccifera L. garrigue : early results, Proceedings annual : Tall Timbers Fire Ecology Conference, Tallahassee, Florida ; 1974. p. 97-129.

Trabaud L. Impact biologique et écologique des feux de végétation sur l'organisation, la structure et l'évolution de la végétation des zones de garrigues du Bas-Languedoc, Thèse, Université des Sciences et Techniques du Languedoc ; 1980.

Trabaud L. Evolution après incendie de la structure de quelques phytocénoses méditerranéennes du Bas-Languedoc (Sud de la France), Ann. Sci. For. 1983 ; 2 (40) : 177-196.

Trabaud L. Fire resistence of Quercus coccifera L. garrigue, Proceeding of the third International Symposium on Fire Ecology, Freiburg, FRG, may 1989, In : Fire in Ecosystems Dynamics; 1989. p. 21-32.

Trabaud L. Recovery of burnt Pinus halepensis Mill. forests. I. Understorey and litter phytomass development after wildfire. Forest Ecology and Management $1985 ; 12$ : 269-277.

Trabaud L. Fire Regimes and Phytomass Growth Dynamics in a Quercus Coccifera Garrigue. Journal of Vegetation Science 1991 ; 2(3): 307-314.

Trabaud L, Lepart J. Changes in the floristic composition of a Quercus coccifera L. garrigue in relation to different fire regimes. Vegetatio 1981 ; 46: 105-116.

van Wagtendonk JW. Use of deterministic fire growth model to test fuel treatments, Center for Water and Wildland Resources, University of California, Davis, CA. ; 1996.

Wade D, Lunsford JD. A guide for prescribed fire in Southern forests, Atlanta, Georgia ; 1989.

Wright HA, Bailey AW. Fire ecology, United States and Southern Canada. John Wiley \& Sons, New York ; 1982.

Xanthopoulos G, Caballero D, Galante M, Alexandrian D, Rigolot E, Marzano R. Forest fuels management in Europe. In: P.L. Andrews and B.W. Butler (Editors), Fuels management. How to measure success. USDA Forest Service, Fort Collins, CO (USA) Portland, OR (USA) ; 2006. p. 29-46. 
Version définitive du manuscrit publié dans / Final version of the manuscript published in : Ecological Modelling, 2011, vol.222, no.8, DOI: 10.1016/j.ecolmodel.2011.02.004

\section{Figure captions}

2

Figure 1. Location of the Petit Luberon State forest area and the five fuel-breaks network. Areas of the two fuel breaks studied, Trou-du-Rat and Mayorques, are represented by black lines on State forest vegetation map.

Figure 2. Top view of the fuel scene.

Figure 3. Total fine fuel load (t.ha $\left.{ }^{-1}\right)$ for the different fuel complexes at the different stages. The dashed line represents the biomass of the untreated plot for a given community.

Figure 4. Wind profile computed with FIRETEC in the lower part of the domain for the control stage of the fuel complexes.

These data were extracted after 30 s of real-time computation (just before ignition), at $\mathrm{x}=160 \mathrm{~m}$

Figure 5. Views of fire propagation in the Control stage for a) Pure pine stand, b) Dense oak coppice, c) Sparse oak coppice and d) Kermes oak garrigue.

Figures 1, 2 and 5 are intended for color reproduction on the web and in print 
Version définitive du manuscrit publié dans / Final version of the manuscript published in : Ecological Modelling, 2011, vol.222, no.8, DOI: 10.1016/j.ecolmodel.2011.02.004

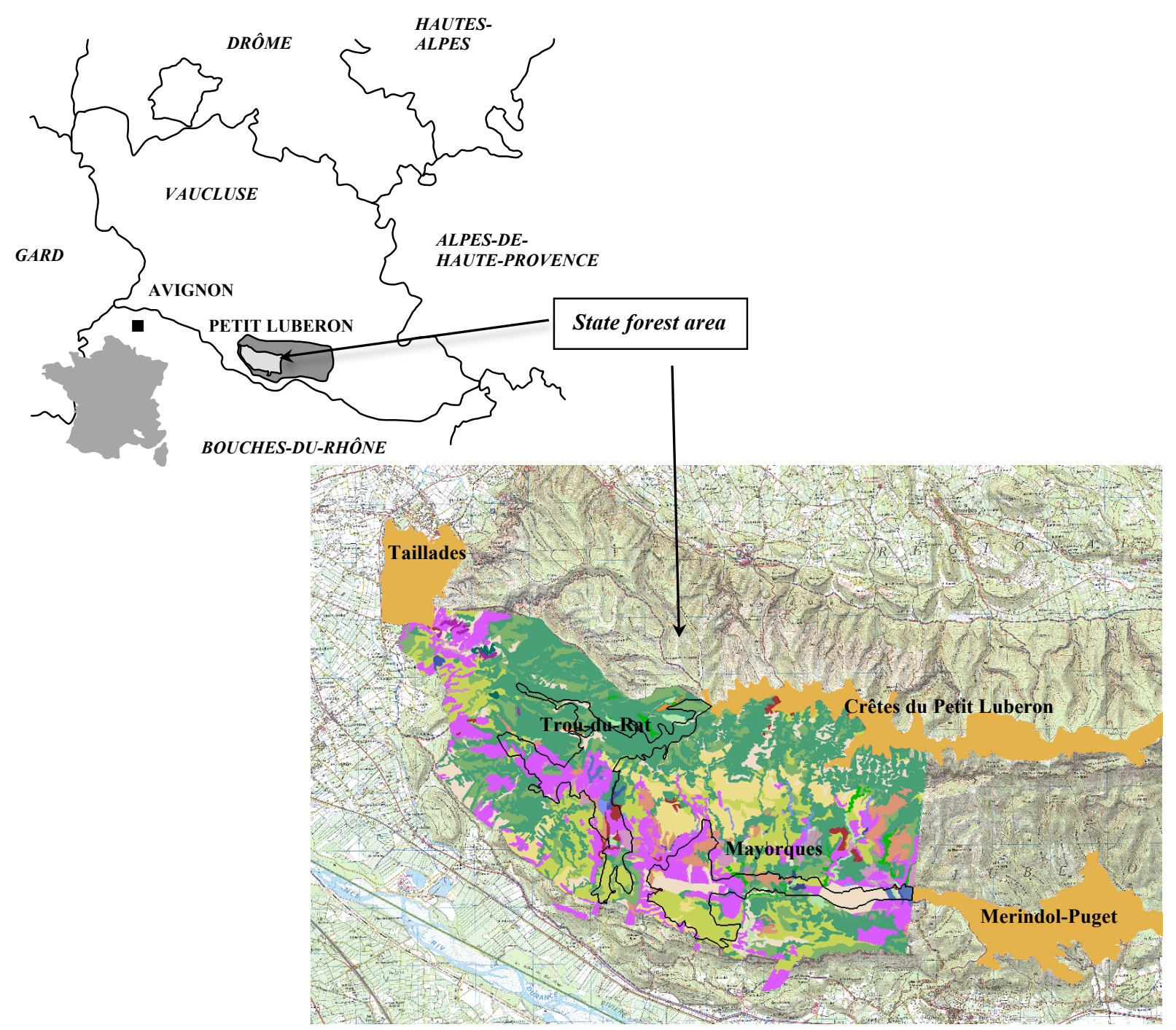

Legend:

(from SIG_EAM ONF Avignon, 2008)

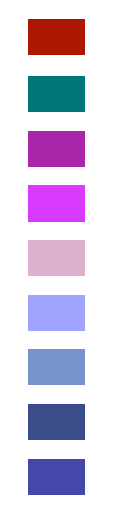

Cedrus plantation: Cedrus atlantica

Mixed stand : Quercus ilex and Cedrus atlantica

Mixed stand : Pinus halepensis and Cedrus atlantica

Pine stand : Pinus halepensis

Mixed stand : Pinus halepensis and Quercus ilex

Pine stand : Pinus Brutia

Pine stand : Pinus nigra subsp laricio

Pine stand : Pinus nigra

Pine stand : other Conifers
Oak stand: Quercus pubescens

Dense oak stand : Quercus ilex

Sparse oak stand: Quercus ilex

Mixed stand: Ouercus pubescens and Ouercus ilex

Broad-leaved garrigue

Garrigue with trees

Garrigue without trees

Heathland

Grassland

Figure 1 


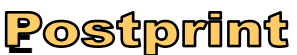

Version définitive du manuscrit publié dans / Final version of the manuscript published in : Ecological Modelling, 2011, vol.222, no.8, DOI: 10.1016/j.ecolmodel.2011.02.004

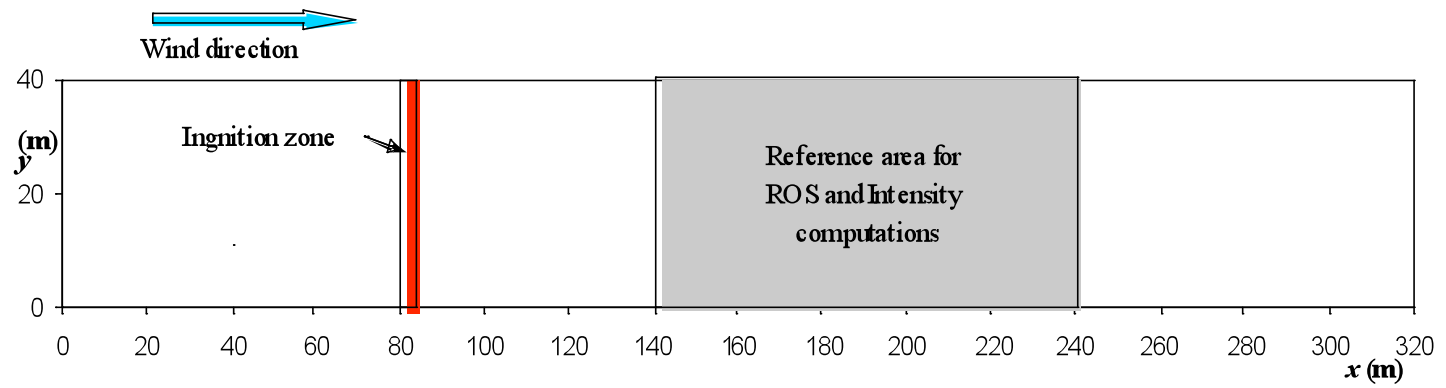

Figure 2 
Version définitive du manuscrit publié dans / Final version of the manuscript published in : Ecological Modelling, 2011, vol.222, no.8, DOI: 10.1016/j.ecolmodel.2011.02.004
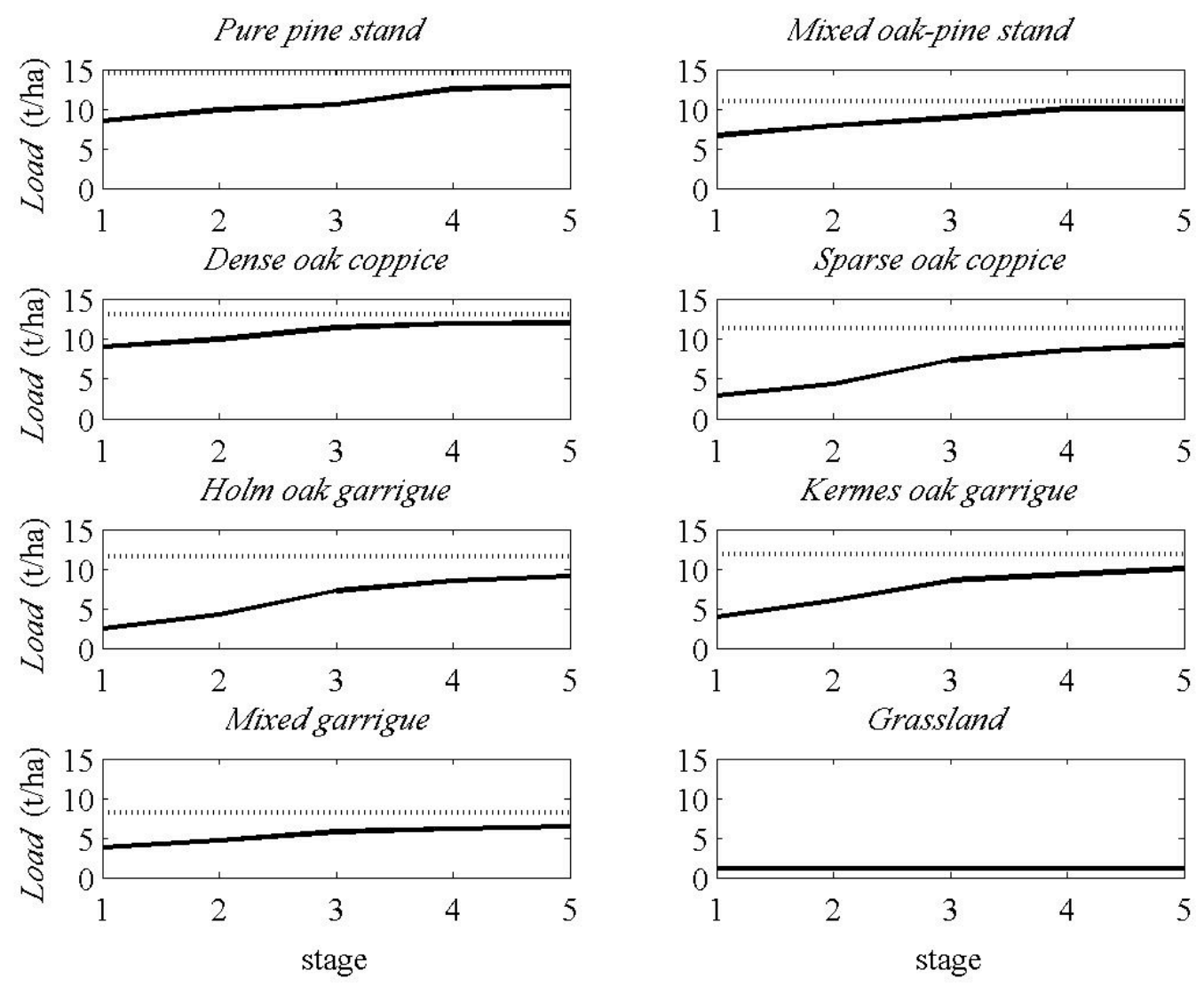

Figure 3 
Version définitive du manuscrit publié dans / Final version of the manuscript published in : Ecological Modelling, 2011, vol.222, no.8, DOI: 10.1016/j.ecolmodel.2011.02.004
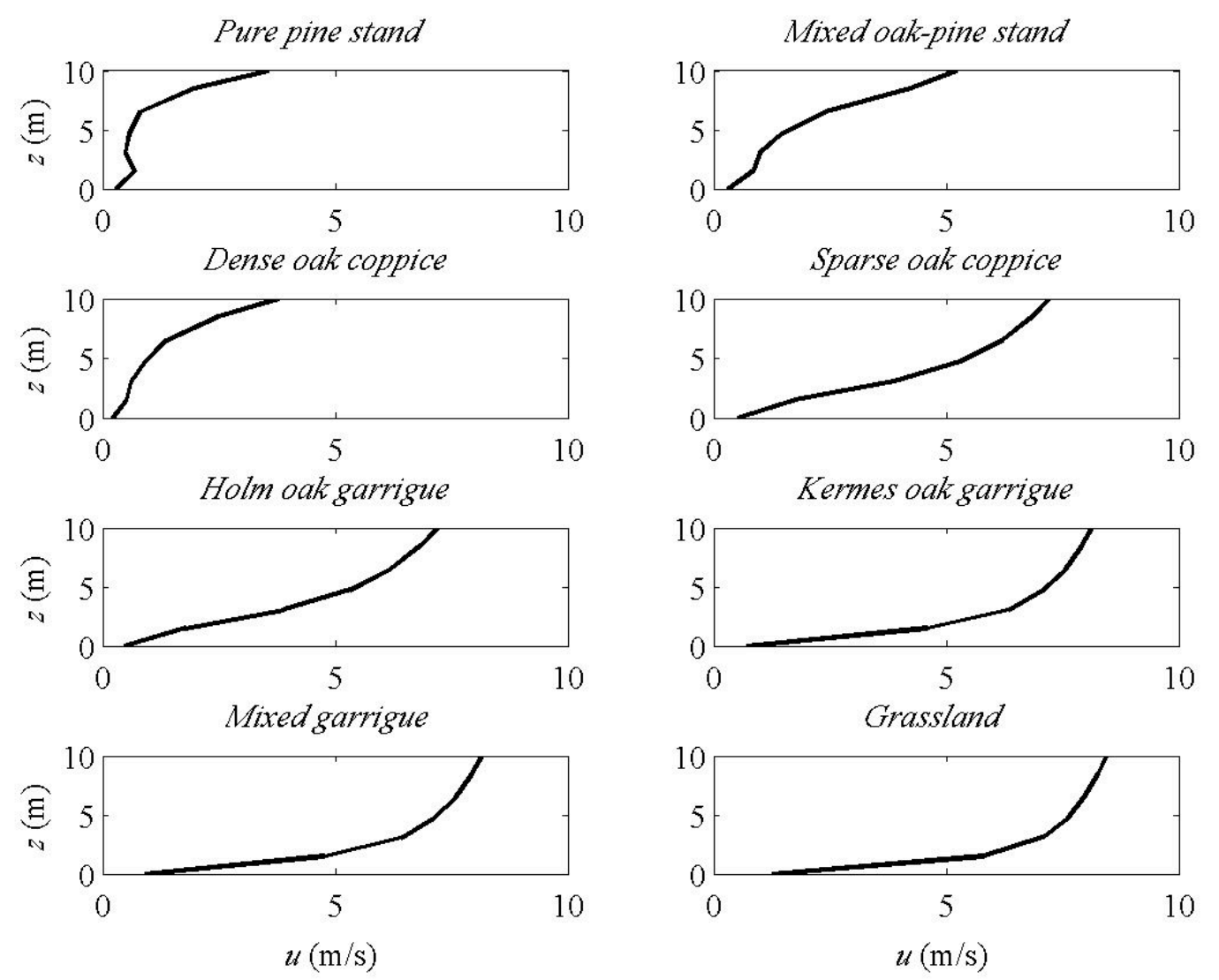

Figure 4 


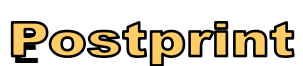

Version définitive du manuscrit publié dans / Final version of the manuscript published in : Ecological Modelling, 2011, vol.222, no.8, DOI: 10.1016/j.ecolmodel.2011.02.004

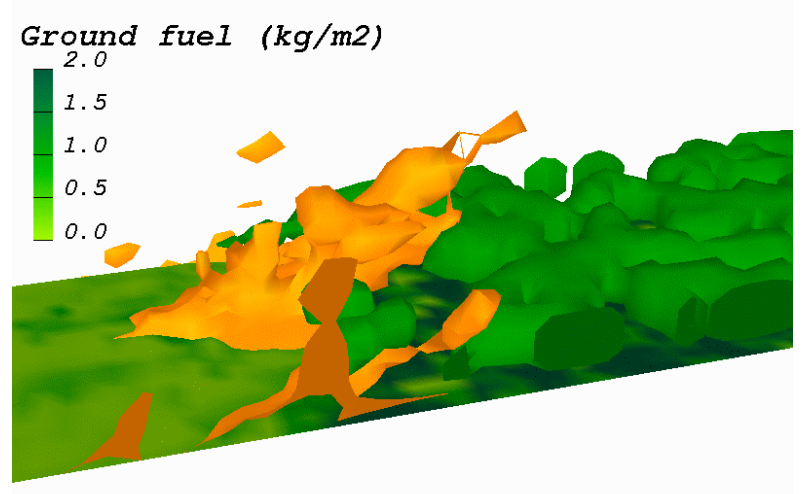

5.a) Pine stand (C), 4min after ignition

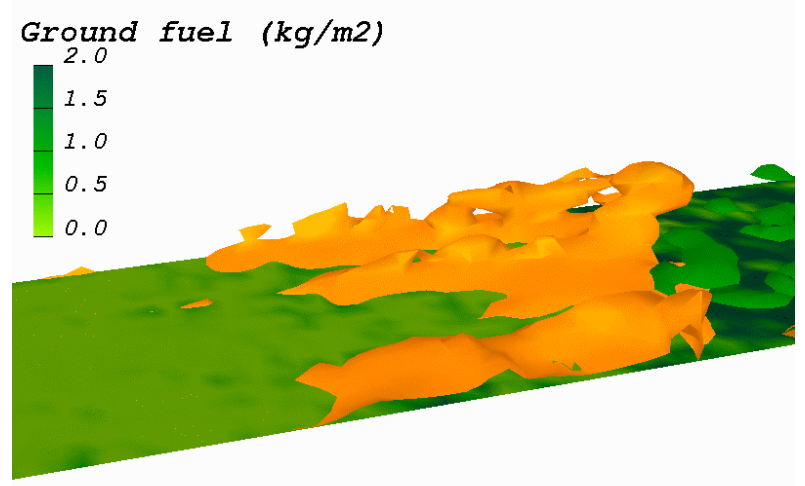

5.c) Sparse coppice (C), 4min after ignition

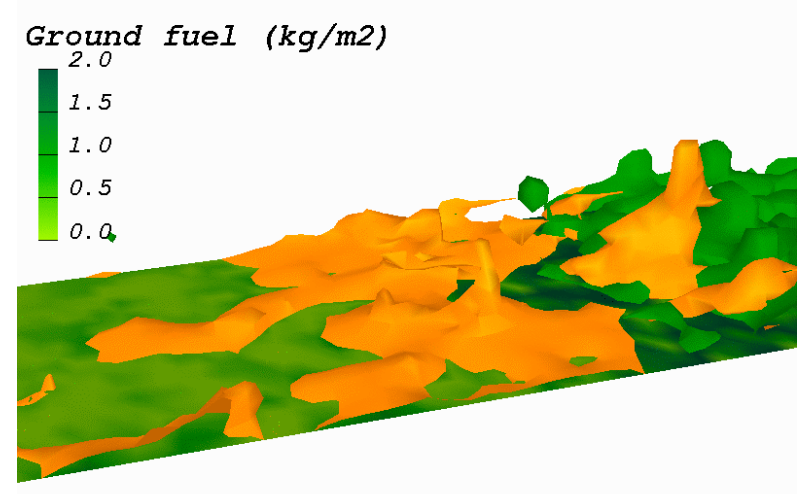

5.b) Dense coppice (C), 3min after ignition

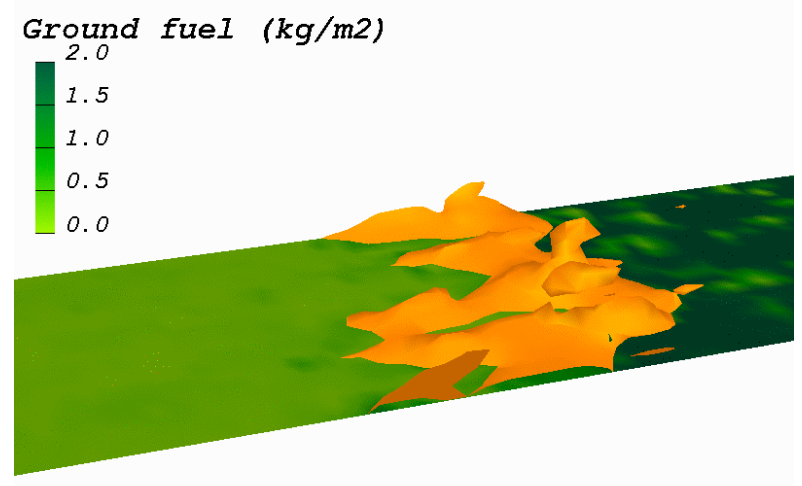

5.d) Kermes garrigue (C), $5 \mathrm{~min} 30 \mathrm{sec}$ after ignition

\section{Figure 5}


Table 1. Characteristics of the eight untreated plant communities selected at their maximum phytovolume (Control stage) and their shrub fuel load.

(h: height; cbh: crown base height; $C$ : cover fraction)

\begin{tabular}{|c|c|c|c|c|c|c|c|c|c|c|c|}
\hline Plant communities & Tree species & $\mathrm{h}$ & cbh & $\mathrm{C}$ & Shrub species & $\mathrm{h}$ & $\mathrm{C}$ & Herb species & $\mathrm{h}$ & $\mathrm{C}$ & Fuel load (t/ha) \\
\hline Pure pine stand & Pinus halepensis & $9 \mathrm{~m}$ & $3 \mathrm{~m}$ & $50 \%$ & $\begin{array}{l}\text { Quercus coccifera } \\
\text { Quercus ilex } \\
\text { Rosmarinus officinalis }\end{array}$ & $\begin{array}{l}0.6 \mathrm{~m} \\
1.2 \mathrm{~m} \\
0.7 \mathrm{~m}\end{array}$ & $\begin{array}{l}49 \% \\
11 \% \\
11 \%\end{array}$ & Brachypodium retusum & $0.25 \mathrm{~m}$ & $30 \%$ & 9.7 \\
\hline Mixed oak-pine stand & $\begin{array}{l}\text { Pinus halepensis } \\
\text { Quercus ilex }\end{array}$ & $\begin{array}{l}7.5 \mathrm{~m} \\
4.5 \mathrm{~m}\end{array}$ & $\begin{array}{c}2.5 \mathrm{~m} \\
0 \mathrm{~m}\end{array}$ & $\begin{array}{l}20 \% \\
15 \%\end{array}$ & $\begin{array}{l}\text { Quercus coccifera } \\
\text { Quercus ilex } \\
\text { Rosmarinus officinalis }\end{array}$ & $\begin{array}{l}0.6 \mathrm{~m} \\
0.6 \mathrm{~m} \\
0.7 \mathrm{~m}\end{array}$ & $\begin{array}{c}36 \% \\
15 \% \\
9 \%\end{array}$ & Brachypodium retusum & $0.25 \mathrm{~m}$ & $30 \%$ & 8.22 \\
\hline Dense oak coppice & $\begin{array}{l}\text { Quercus ilex } \\
\text { Pinus halepensis }\end{array}$ & $\begin{array}{l}4 m \\
9 m\end{array}$ & $\begin{array}{l}0.5-1 \mathrm{~m} \\
3 \mathrm{~m}\end{array}$ & $\begin{array}{l}50 \% \\
15 \%\end{array}$ & $\begin{array}{l}\text { Quercus coccifera } \\
\text { Quercus ilex } \\
\text { Rosmarinus officinalis }\end{array}$ & $\begin{array}{c}0.6 \mathrm{~m} \\
0.75 \mathrm{~m} \\
0.5 \mathrm{~m}\end{array}$ & $\begin{array}{l}30 \% \\
15 \% \\
15 \%\end{array}$ & Brachypodium retusum & $0.25 \mathrm{~m}$ & $30 \%$ & 8.84 \\
\hline Sparse oak coppice & Quercus ilex & $3 \mathrm{~m}$ & $0.5-1 \mathrm{~m}$ & $25 \%$ & $\begin{array}{l}\text { Quercus ilex } \\
\text { Cistus alba }\end{array}$ & $\begin{array}{l}1.5 \mathrm{~m} \\
0.5 \mathrm{~m}\end{array}$ & $\begin{array}{l}40 \% \\
10 \%\end{array}$ & Brachypodium retusum & $0.25 \mathrm{~m}$ & $30 \%$ & 10.36 \\
\hline Holm oak garrigue & Quercus ilex & $3 \mathrm{~m}$ & $0 \mathrm{~m}$ & $10 \%$ & $\begin{array}{l}\text { Quercus ilex } \\
\text { Cistus alba }\end{array}$ & $\begin{array}{l}1.5 \mathrm{~m} \\
0.6 \mathrm{~m}\end{array}$ & $\begin{array}{l}40 \% \\
20 \%\end{array}$ & Brachypodium retusum & $0.25 \mathrm{~m}$ & $30 \%$ & 10.82 \\
\hline Kermes oak garrigue & & & & & $\begin{array}{l}\text { Quercus coccifera } \\
\text { Quercus ilex }\end{array}$ & $\begin{array}{l}0.7 \mathrm{~m} \\
1.2 \mathrm{~m}\end{array}$ & $\begin{array}{l}64 \% \\
16 \%\end{array}$ & Brachypodium retusum & $0.25 \mathrm{~m}$ & $30 \%$ & 11.44 \\
\hline Mixed garrigue & & & & & $\begin{array}{l}\text { Quercus coccifera } \\
\text { Rosmarinus officinalis }\end{array}$ & $\begin{array}{l}0.75 \mathrm{~m} \\
1 \mathrm{~m}\end{array}$ & $\begin{array}{l}48 \% \\
20 \%\end{array}$ & Brachypodium retusum & $0.25 \mathrm{~m}$ & $30 \%$ & 7.88 \\
\hline Grassland & & & & & & & & Brachypodium retusum & $0.25 \mathrm{~m}$ & $100 \%$ & 1.1 \\
\hline
\end{tabular}


Table 2. Characteristic of shrub fuel complexes at the different stages after treatment expressed in height and cover fraction and their shrub fuel load (Qc: Quercus coccifera; Qi: Quercus ilex; Ro: Rosmarinus officinalis; Ca: Cistus alba)

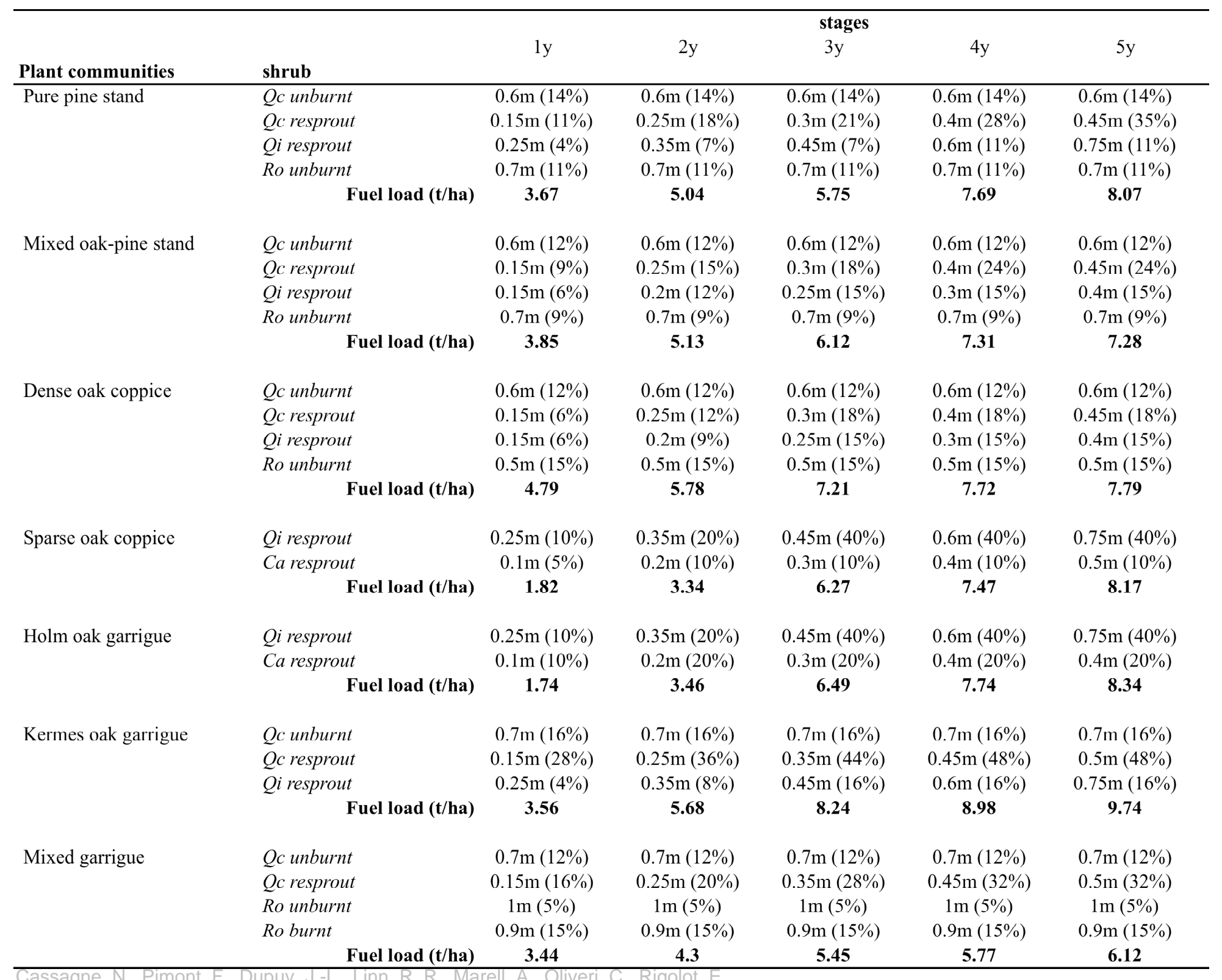




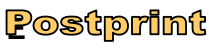

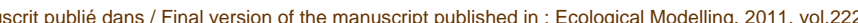

no.8, DOl: 10.101

Table 3. Fine fuel physical properties for each species.

\begin{tabular}{|c|c|c|c|c|c|c|c|c|c|c|}
\hline \multirow[b]{2}{*}{ Parameters } & \multirow[t]{2}{*}{ Pinus halepensis } & \multicolumn{2}{|c|}{ Quercus ilex } & \multirow{2}{*}{\multicolumn{2}{|c|}{ Quercus coccif era }} & \multirow{2}{*}{\multicolumn{2}{|c|}{$\begin{array}{r}\text { Rosmarinus of } f \text { icinalis } \\
\text { (dead) }\end{array}$}} & \multirow{2}{*}{\multicolumn{2}{|c|}{ Cistus alba }} & \multirow[t]{2}{*}{ Brachypodium retusum } \\
\hline & & trees & shrubs & & & & & & & \\
\hline \multirow[t]{2}{*}{$\rho\left(\mathrm{kg} \cdot \mathrm{m}^{-3}\right)$} & 0.15 & $0.25-0.4$ & $2.11-3.26$ & & $55-3.31$ & $1.17-1.64$ & 0.5 & & $85-1.3$ & 0.44 \\
\hline & leaves & leaves & twigs $0-2 \mathrm{~mm}$ & leaves & twigs $0-2 \mathrm{~mm}$ & leaves & twigs $0-2 \mathrm{~mm}$ & leaves & twigs $0-2 \mathrm{~mm}$ & leaves \\
\hline$\sigma\left(\mathrm{m}^{-1}\right)$ & 9000 & 4054 & 2452 & 5818 & 2870 & 4383 & 2641 & 3640 & 2590 & 20000 \\
\hline $\mathrm{MC}(\%)$ & 100 & & 74 & & 76 & & $(20)$ & & 72 & 15 \\
\hline
\end{tabular}


Version définitive du manuscrit publié dans / Final version of the manuscript published in : Ecological Modelling, 2011, vol.222, no.8, DOI: 10.1016/j.ecolmodel.2011.02.004

Table 4. Fire intensity computed in the different fuel complexes (in $\mathrm{kW} \cdot \mathrm{m}^{-1}$ )

\begin{tabular}{lcccccc}
\hline \multicolumn{1}{c}{ Stage } & & & & & & \\
Plant Community & 1 & 2 & 3 & 4 & 5 & Control \\
\hline Pure pine stand & $(1300)$ & $(1500)$ & $(2000)$ & 6000 & 5800 & 5500 \\
Mixed oak-pine & $(600)$ & $(730)$ & 2300 & 5500 & 5500 & 5800 \\
Dense oak coppice & $(1500)$ & 2000 & 13100 & 13800 & 13900 & 14800 \\
Sparse oak coppice & $(650)$ & 900 & 8100 & 9300 & 9400 & 10500 \\
Holm oak garrigue & $(350)$ & 1600 & 6400 & 6400 & 6600 & 7700 \\
Kermes oak garrigue & $(900)$ & 3600 & 5300 & 5400 & 5600 & 6300 \\
Mixed garrigue & 1500 & 3300 & 5800 & 5900 & 5700 & 6000 \\
Grassland & 900 & 900 & 900 & 900 & 900 & 900 \\
\hline NB: the
\end{tabular}

NB: the numbers in brackets correspond to initial intensity (for runs where the fire stopped) 
Version définitive du manuscrit publié dans / Final version of the manuscript published in : Ecological Modelling, 2011, vol.222, no.8, DOI: 10.1016/j.ecolmodel.2011.02.004

Table 5. Firefront Rate Of Spread (ROS) for the different fuel complexes (in $\mathrm{m.s}^{-1}$ )

\begin{tabular}{lcccccc}
\hline \multicolumn{1}{c}{ Stage } & & & & & & \\
Plant community & 1 & 2 & 3 & 4 & 5 & Control \\
\hline Pure pine stand & $(0.12)$ & $(0.14)$ & $(0.2)$ & 0.37 & 0.35 & 0.28 \\
Mixed oak-pine & $(0.3)$ & $(0.16)$ & 0.16 & 0.45 & 0.41 & 0.37 \\
Dense oak coppice & $(0.2)$ & 0.29 & 0.7 & 0.7 & 0.73 & 0.75 \\
Sparse oak coppice & $(0.23)$ & 0.29 & 0.7 & 0.65 & 0.6 & 0.53 \\
Holm oak garrigue & $(0.3)$ & 0.37 & 0.54 & 0.47 & 0.44 & 0.39 \\
Kermes oak garrigue & $(0.32)$ & 0.43 & 0.38 & 0.38 & 0.34 & 0.34 \\
Mixed garrigue & 0.35 & 0.57 & 0.59 & 0.6 & 0.54 & 0.43 \\
Grassland & 0.82 & 0.82 & 0.82 & 0.82 & 0.82 & 0.82 \\
\hline NB: the numbers in brackets correspond to initial ROS (for runs where the fire stopped)
\end{tabular}


Version définitive du manuscrit publié dans / Final version of the manuscript published in : Ecological Modelling, 2011, vol.222, no.8, DOI: 10.1016/j.ecolmodel.2011.02.004

Table 6. Distances covered by the fire before extinction

\begin{tabular}{lc}
\hline Fuel complexes & Distances (m) \\
\hline Pure pine stand (1y) & 15 \\
Pure pine stand (2y) & 26 \\
Pure pine stand (3y) & 64 \\
Mixed oak-pine (1y) & 22 \\
Mixed oak-pine (2y) & 84 \\
Dense oak coppice (1y) & 32 \\
Sparse oak coppice (1y) & 24 \\
Holm oak garrigue (1y) & 12 \\
Kermes oak garrigue (1y) & 30 \\
\hline
\end{tabular}

